\title{
Circulating MicroRNAs in Newly Diagnosed Acute and Chronic Leukemias
}

\author{
Anil TOMBAK ${ }^{1}$, Aysegul GORUR ${ }^{2}$, Senay BALCI², Naci TIFTIK ${ }^{1}$, Lulufer TAMER ${ }^{2}$ \\ ${ }^{1}$ Mersin University Faculty of Medicine, Department of Hematology \\ ${ }^{2}$ Mersin University Faculty of Medicine, Department of Biochemistry, Mersin, TURKEY
}

\begin{abstract}
Leukemia is a clonal disease caused by genetic-epigenetic aberrations and we investigated the profile of circulating 741 microRNAs (miRNA) in plasma of newly diagnosed acute lymphoblastic leukemia (ALL), acute myeloid leukemia (AML), chronic lymphocytic leukemia (CLL), chronic myeloid leukemia (CML) patients compared to healthy individuals. MiRNAs are small non-coding RNA molecules and have critical roles in cell differentiation, proliferation, apoptosis. They regulate haematopoiesis in haematopoietic stem cells and committed progenitor cells, but they also play role in pathogenesis of acquired hematologic neoplasms. Recently, a growing body of evidence has implicated specific miRNAs in pathogenesis of leukemia and circulating miRNAs could serve as non-invasive biomarkers for detection of leukemia. Aim of this study was to identify miRNAs epigenetically regulated in acute and chronic leukemias. RNA was isolated using High Pure miRNA Isolation Kit (Roche) following manufacturer's protocol. cDNA and preamplification protocols were obtained from isolated plasma miRNAs. The BioMarkTM 96.96 Dynamic Array (Fluidigm Corporation) for real-time qPCR was used to simultaneously quantite the expression of 741 miRNAs. Statistical analyses were performed using Biogazelle's qbase PLUS 2.0 software. Among analyzed 741 miRNAs, mir-1290 and miR-548c-3p were down-regulated, mir-24-3p, miR-30b$5 p$ and miR-19a-3p were up-regulated in all leukemic patients comparing with control group $(p<0.05)$. However, in patients with ALL, mir-24-3p was significantly down-regulated and miR-548c-3p was significantly up-regulated compared to healthy subjects ( $p<$ 0.05). Our study is the first study showing the higher expression levels of miR-548c-3p in ALL. We conclude that miR-24-3p and miR-548c-3p can be used as potential biomarkers for detecting ALL.
\end{abstract}

Keywords: microRNA, Leukemia, ALL, Biomarker

\section{ÖZET}

\section{Yeni Tanı Konulmuş Akut ve Kronik Lösemilerde Dolaşımdaki MikroRNA'lar}

Lösemi, genetik-epigenetik bozukluklar nedeniyle gelişen klonal bir hastalıktır ve bu çalışmada, sağlıklı bireylere kıyasla yeni tanı almış akut lenfositik lösemi (ALL), akut miyeloid lösemi (AML), kronik lenfositik lösemi (KLL), kronik miyeloid lösemi (KML) hastalarının plazmalarındaki 741 mikroRNA'nın (miRNA) dolaşımdaki profilini araştırdık. MiRNA'lar, küçük, kodlanmayan RNA molekülleridir ve hücre diferansiyasyonunda, proliferasyonunda, apoptoziste kritik rollere sahiptirler. Hematopoetik kök hücrelerde ve progenitor hücrelerde hematopoezisi düzenlerler, aynı zamanda akkiz hematolojik neoplazilerin patogenezinde de rol alırlar. Son dönemlerde, lösemi patogenezinde özgül miRNA'ların etkinliğine dair kanıtlar giderek artmaktadır ve löseminin tespitinde dolaşımdaki miRNA'lar invaziv olmayan bir biyobelirteç olarak kullanılabilir. Bu çalışmada, akut ve kronik lösemilerdeki epigenetik olarak düzenlenen miRNA'ların tespiti amaçlanmıştır. RNA, üreticinin protokolüne uygun şekilde High Pure miRNA Isolation Kit (Roche) kullanılarak izole edildi. cDNA ve preamplifikasyon protokolleri izole edilmiş plazma miRNA'larından elde edildi. 741 miRNA'nın ekspresyonunu aynı anda ölçmek için qPCR'de BioMarkTM 96.96 Dynamic Array (Fluidigm Corporation) kullanıldı. İstatistiksel analizler Biogazelle's qbase PLUS 2.0 software kullanılarak yapıldı. 741 miRNA'nın analizi sonucunda, kontrol grubuna kıyasla tüm lösemi hastalarında miR-1290 ve miR548c-3p ekspresyonunun azaldığı, miR-24-3p, miR-30b-5p ve miR-19a-3p ekspresyonunun arttığı saptandı ( $p<0.05)$. Bununla beraber, ALL'li hastalarda sağlıkı bireylere kıyasla miR-24-3p ekspresyonunun belirgin olarak azaldığı ve miR-548c-3p ekspresyonunun ise belirgin olarak arttığı görüldü ( $p<0.05$ ). Bu çalışma, ALL'de miR-548c-3p'nin yüksek ekspresyonunu gösteren ilk çalışmadır. MiR-24-3p'nin ve miR-548c-3p'nin ALL tespitinde potansiyel biyobelirteçler olarak kullanılabileceğini düşünüyoruz.

Anahtar Kelimeler: mikroRNA, Lösemi, ALL, Biyobelirteç 


\section{INTRODUCTION}

Leukemia is a complex clonal disorder of the bone marrow, characterized by the abnormal proliferation of immature blood cells. Clinically and pathologically, leukemia is subdivided into a variety of large groups. They include: acute lymphoblastic leukemia (ALL), acute myeloid leukemia (AML), chronic lymphocytic leukemia (CLL) and chronic myeloid leukemia (CML) among others. While acute leukemias are characterized by a rapid increase in the number of immature blood cells, chronic leukemias are characterized by the excessive build up of relatively mature, but still abnormal white blood cells. Immediate treatment is required in acute leukemia due to the rapid progression and accumulation of the malignant cells; however, chronic leukemias are typically taking months or years to progress and are sometimes monitored for some time before treatment to ensure maximum effectiveness of therapy. ${ }^{1}$ In many types of leukemias the underlying causative genetic insults are not fully described. Leukemias are highly diverse diseases and have been shown to be associated with microRNA (miRNA) expression aberrations.

MiRNAs are 18-24 nucleotide single stranded non-protein-coding RNAs. They function as gene repressors by binding to target messenger RNAs (mRNA) to regulate gene expression and protein expression by repressing translation or destabilizing mRNA target at posttranscriptional level and have critical roles in regulation of cell differentiation, proliferation, apoptosis. ${ }^{2,3}$ MiRNAs are tissue-specific; different miRNAs are expressed in different cell types and they can be detected in peripheral blood.

MiRNAs regulate normal haematopoiesis in both haematopoietic stem cells and committed progenitor cells, but they also play a role in the pathogenesis of some acquired hematologic neoplasms and aberrant miRNA expression has been documented in multiple haematologic malignancies. ${ }^{4,5}$ Deregulated expression of miRNAs is associated with neoplasia through tumor suppressor gene downregulation or oncogene overexpression. ${ }^{6-8}$ Recently, a growing body of evidence has implicated specific miRNAs in the pathogenesis of leukemia and circulating miRNAs could serve as non-invasive biomarkers for detection of leukemia at the time of diagnosis and relapse. In this study, we investigated the profile of circulating 741 miRNAs in the plasma of newly diagnosed ALL, AML, CLL and CML patients compared to healthy individuals.

\section{PATIENTS and METHODS}

\section{Patients and Samples}

Patients with newly diagnosed ALL, AML, CLL, CML and healthy subjects as control group were included into the study. Peripheral blood samples of 22 ALL, 5 AML, 8 CLL, 4 CML patients and 80 healthy subjects were obtained by venipuncture in tubes containing 2\% EDTA with approval of local Ethics Committee of Mersin University Medical Faculty. Informed consent was obtained in accordance with the Declaration of Helsinki. The diagnosis of ALL and AML were established according to the criteria of the French-American-British (FAB) classification by standard morphological and immunophenotypic methods; patients with AML were classified as M0 to M3 subtypes and patients with ALL were classified as L1 and L3 subtypes. Patients' characteristics were shown in Table 1.

\section{Plasma Preparation and RNA Isolation}

Plasma samples were collected via centrifuging EDTA blood samples at $4,000 \mathrm{rpm}$ for $15 \mathrm{~min}$ within $2 \mathrm{~h}$ of collection. Plasma samples were transferred into a clean microcentrifuge tube followed by a second high-speed centrifugation step at $13,000 \mathrm{rpm}$ for $5 \mathrm{~min}$ at $10^{\circ} \mathrm{C}$ to remove cell debris and fragments. The plasma samples were aliquoted and stored at $-80^{\circ} \mathrm{C}$ until RNA extraction. Total RNA (including miRNAs) was extracted from plasma by using high-pure miRNA isolation kit (Roche diagnostic GmbH, Mannheim, Germany) according to manufacturer's instructions and then stored at $-80^{\circ} \mathrm{C}$ for further process.

\section{Reverse Transcription (RT) Reaction}

Total RNA samples $(2 \mu \mathrm{l})$ were reverse-transcribed using Taqman MicroRNA reverse transcription kit 
Table 1. Patient characteristics (ALL: acute lymphoblastic leukemia, AML: acute myeloid leukemia, CLL: chronic lymphocytic leukemia, CML: chronic myeloid leukemia, FAB: French-American-British)

\begin{tabular}{|c|c|c|}
\hline & Mean & $\begin{array}{l}\text { Number of } \\
\text { participants } \\
\text { n (\%) }\end{array}$ \\
\hline Total number of patients & & 39 \\
\hline Patients with ALL & & $22(56.4)$ \\
\hline Age (years) & $15.6 \pm 15.0$ & \\
\hline \multicolumn{3}{|l|}{ Sex } \\
\hline Male & & $13(59.1)$ \\
\hline Female & & $9(40.9)$ \\
\hline \multicolumn{3}{|l|}{ FAB classification } \\
\hline L1 & & $18(81.8)$ \\
\hline L3 & & 4 (18.2) \\
\hline Patients with AML & & $5(12.8)$ \\
\hline Age (years) & $40.6 \pm 20.9$ & \\
\hline \multicolumn{3}{|l|}{ Sex } \\
\hline Male & & $4(80.0)$ \\
\hline Femal & & $1(20.0)$ \\
\hline \multicolumn{3}{|l|}{ FAB classification } \\
\hline MO & & $1(20.0)$ \\
\hline M1 & & $1(20.0)$ \\
\hline M3 & & $3(60.0)$ \\
\hline Patients with CLL & & $8(20.5)$ \\
\hline Age (years) & $59.3 \pm 11.0$ & \\
\hline \multicolumn{3}{|l|}{ Sex } \\
\hline Male & & $1(12.5)$ \\
\hline Female & & 7 (87.5) \\
\hline Patients with $\mathrm{CML}$ & & $4(10.3)$ \\
\hline Age (years) & $63.3 \pm 21.0$ & \\
\hline \multicolumn{3}{|l|}{ Sex } \\
\hline Male & & $2(50.0)$ \\
\hline Female & & $2(50.0)$ \\
\hline \multicolumn{3}{|l|}{ Total number of healthy } \\
\hline participants (control group) & & 80 \\
\hline Age (years) & $27.83 \pm 10.12$ & \\
\hline \multicolumn{3}{|l|}{ Sex } \\
\hline Male & & $52(65)$ \\
\hline Female & & $28(35)$ \\
\hline
\end{tabular}

in combination with Megaplex RT primer Human pool set A and B (Applied Biosystems, Foster City, CA, USA), allowing simultaneous reverse transcription of 741 miRNAs and three endogen controls (U6 snRNA, RNU44 and RNU48). Briefly, 2 $\mu l$ of total RNA was supplemented with Megaplex RT primer mix (10X), RT buffer (10X), Multiscribe reverse transcriptase $(50 \mathrm{U} / \mu \mathrm{l})$, dNTPs with $\operatorname{dTTP}(100 \mathrm{mM}), \mathrm{MgCl}_{2}(25 \mathrm{mM})$ and RNase inhibitor $(20 \mathrm{U} / \mu \mathrm{l})$ in a total reaction volume of 5 $\mu 1$. RT reaction was used $\left(40\right.$ cycles of $16^{\circ} \mathrm{C}$ for $2 \mathrm{~min}, 42^{\circ} \mathrm{C}$ for $1 \mathrm{~min}$ and $50^{\circ} \mathrm{C}$ for $1 \mathrm{~s}$, followed by a final reverse transcriptase inactivation at $85^{\circ} \mathrm{C}$ for $5 \mathrm{~min}$ ). cDNA samples were kept at $-80^{\circ} \mathrm{C}$ until PCR analysis.

\section{Pre-amplification of cDNA}

For pre-amplification, $2 \mu 1$ of cDNA samples was transferred into a clean 96-well plate and $8 \mu \mathrm{l}$ of DNA suspension buffer was added on the top of cDNAs and mixed by pipetting up and down 5-6 times. One-fifth of diluted RT product (2X) was pre-amplified using Applied Biosystems' Taqman preamp master mix $(2 \mathrm{X})$ and Megaplex preamp primers $(5 \mathrm{X})$ in a $5 \mu \mathrm{l}$ PCR. The primer pool consisted of forward primers specific to each of the 741 miRNAs and a universal reverse primer (Applied Biosystems). The pre-amplification cycling conditions were as follows: $95^{\circ} \mathrm{C}$ for $10 \mathrm{~min}, 55^{\circ} \mathrm{C}$ for $2 \mathrm{~min}$ and $75^{\circ} \mathrm{C}$ for $2 \mathrm{~min}$ followed by 14 cycles of $95^{\circ} \mathrm{C}$ for $15 \mathrm{~s}$ and $60^{\circ} \mathrm{C}$ for $4 \mathrm{~min}$.

\section{Real-time qPCR}

Pre-amplified cDNA samples were diluted with low-EDTA (0.1 mM) TE buffer (1:5). About 490 $\mu 1$ Taqman universal PCR master mix (no AmpErase UNG) (Applied Biosystems, Foster City, CA, USA) and $49 \mu \mathrm{l}$ (20X) GE sample loading reagent (Fluidigm, PN 85000746) were mixed, and $3.85 \mu \mathrm{l}$ was pipetted into a 96-well plate and added $3.15 \mu \mathrm{l}$ of diluted pre-amplified cDNA into each well and mixed; then $5 \mu \mathrm{l}$ of this mixture was pipetted into sample inlets of a 96.96 dynamic array (Fluidigm, Sout San Francisco, USA), and $4.5 \mu 1$ of miRNA Taqman probe and primers (Applied Biosystems) was pipetted into assay inlets of a 96.96 dynamic array (Fluidigm). The biomark IFC controller HX (Fluidigm, San Francisco, CA, USA) was used to distribute the assay mix and sample mix from the loading inlets into the 96.96 dynamic array reaction chambers for qRT-PCR by Fluidigm's integrated fluidic circuit technology. qRT-PCR was performed using the high-throughput biomark realtime PCR system (Fluidigm, South San Francisco, CA, USA). Cycling conditions were as follows; firstly, thermal mix protocol is followed by $50^{\circ} \mathrm{C}$ 


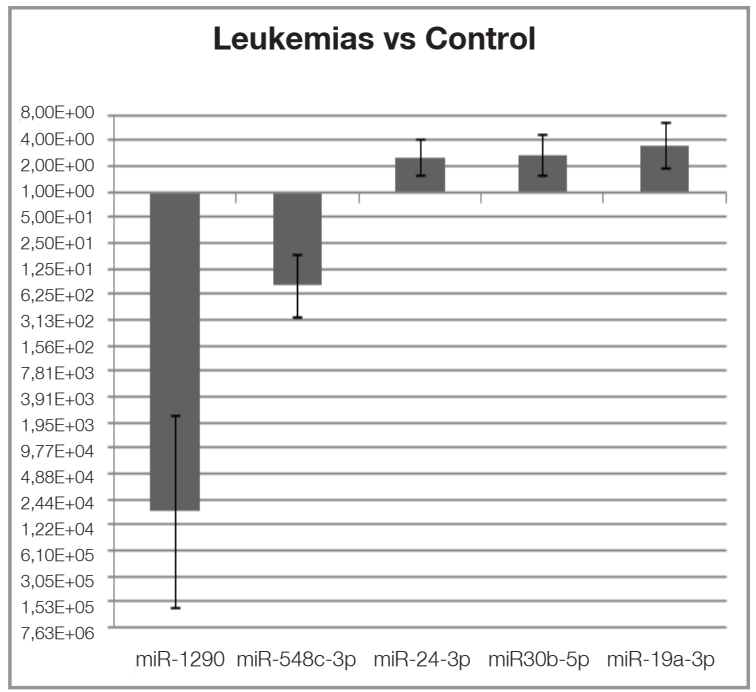

Figure 1. Among 741 miRNAs, mir-1290 and miR-548c-3p were down-regulated, while mir-24-3p, miR-30b-5p and miR-19a-3p were up-regulated in all leukemic patients comparing with the control group $(p<0.05)$.

for $2 \mathrm{~min}, 70^{\circ} \mathrm{C}$ for $30 \mathrm{~min}$ and $25^{\circ} \mathrm{C}$ for $5 \mathrm{~min}$. Then UNG and Hot start protocol is followed by $50^{\circ} \mathrm{C}$ for $2 \mathrm{~min}$ and $95^{\circ} \mathrm{C}$ for $5 \mathrm{~min}$. Finally, PCR cycle is followed by 40 cycles of $95^{\circ} \mathrm{C}$ for $15 \mathrm{~s}$ (denaturation) and $60^{\circ} \mathrm{C}$ for $60 \mathrm{~s}$ (annealing).

\section{Statistical Analysis}

All statistical analyses were performed using the Biogazelle's qBase PLUS 2.0 software which uses global means normalization method in order to troubleshoot the house keeping gene problem in circulation. This qPCR profiling platform that consists of 741 miRNAs were analyzed together by using global mean normalization. Statistical analysis of miRNAs between leukemia and control groups was compared with the Mann-Whitney U test. $\mathrm{P}<0.05$ was considered statistically significant.

\section{RESULTS}

Thirty nine patients with ALL, AML, CLL, CML and 80 healthy subjects as control group were included into this study. Of the 39 patients, 20 $(51.3 \%)$ were men and 19 (48.7\%) were women with a mean age $31.94 \pm 24.6$ years. Of the 80 healthy subjects, $52(65 \%)$ were men and $28(35 \%)$ were women with a mean age $27.83 \pm 10.12$ years.

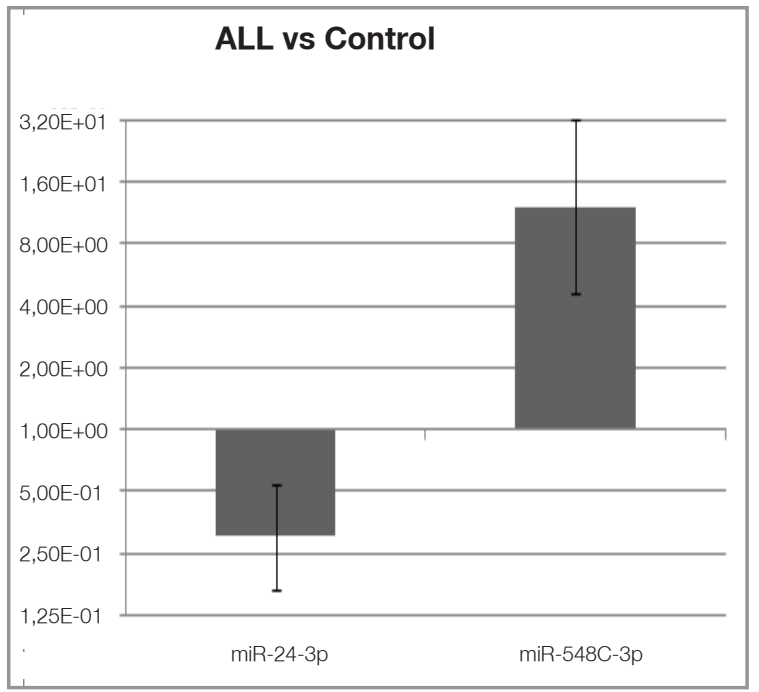

Figure 2. In patients with ALL, mir-24-3p was significantly downregulated and miR-548c-3p was significantly up-regulated compared to the healthy subjects $(p<0.05)$ (ALL: acute lymphoblastic leukemia).

In the study, quantitative real-time PCR was used to obtain the miRNA expression profiles. Among these 741 miRNAs, mir-1290 and miR-548c-3p were down-regulated, while mir-24-3p, miR-30b$5 p$ and miR-19a-3p were up-regulated in all leukemic patients comparing with the control group $(\mathrm{p}<$ 0.05) (Figure 1). However, in patients with ALL, mir-24-3p was significantly down-regulated and miR-548c-3p was significantly up-regulated compared to the healthy subjects $(\mathrm{p}<0.05)$ (Figure 2). In patients with AML, CLL and CML, there was no statistically significant difference among miRNA expressions compared to healthy subjects.

\section{DISCUSSION}

The leukemias are a diverse group of neoplastic diseases. A combination of clinical, cytogenetic, and genetic features with immunophenotype and cell morphology are used to stratify each of the leukemias further into subtypes. Tumourigenesis has long been attributed to the alteration of oncogenes and tumour suppressor genes. ${ }^{9}$ However, the discovery of non-protein-coding miRNAs and their possible associations with cancer has certified suspicions that tumour pathogenicity is far more complex than the simple deregulation of proteincoding genes and warrants further investigation. ${ }^{10}$ 
MiRNAs represent a class of naturally occurring small, non-coding RNA molecules. They regulate gene expression at the post-transcriptional level and control including developmental transitions, organ morphology, cell proliferation and apoptosis. Recently accumulating evidence suggests that miRNAs regulate diverse biological processes and play important roles in several hematologic malignancies, such as acute and chronic leukemias. ${ }^{5,10,11}$ Several studies have identified cancer-specific alterations in plasma/serum miRNAs of cancer patients and have shown the potential of plasma circulating miRNAs to be new non-invasive biomarkers in patients with various cancers. ${ }^{12}$ It has become apparent that miRNAs are key factors in cancer development with their oncogenic or tumour suppressing roles. The discovery of miRNAs provides a new and powerful tool for studying the mechanisms, diagnosis and treatment of malignant diseases. These findings guided us to investigate the beneficial of miRNAs in patients with acute and chronic leukemias. In the present study, we found that mir-24-3p was significantly down-regulated and miR-548c-3p was significantly up-regulated in ALL patients compared to control group $(\mathrm{p}<0.05)$, while miR-24-3p was up-regulated and miR-548c$3 \mathrm{p}$ was down-regulated in all patients compared to control group. In a study conducted by Mi et al., it was shown that miR-24 was expressed at a significantly higher level in AML compared with ALL patients. ${ }^{13}$ Our study is the first study showing the higher expression levels of miR-548c-3p in ALL. MiR-548c-3p may be a novel biomarker in patients with B-cell-ALL. However, it remains unclear as to how mir-24-3p and miR-548c-3p exert their function in ALL patients, because our understanding of miR-24-3p and especially miR-548c-3p pathways is limited. Mir-24 normally inhibits B-cell development and promotes myeloid development of hematopoietic progenitors. The higher expression of miR-24 in AML suggests that its pro-survival activity could contribute to the transformation of hematopoietic cells. ${ }^{14} \mathrm{MiR}-24$ is reported to regulate apoptosis, either positively or negatively depending on cell context ${ }^{14}$ and mir-24-3p depletion may contribute B-cell leukemiagenesis by the inhibition of B-cell apoptosis.
MiR-548 is a recently discovered human miRNA gene family that is derived from the miniature inverted-repeat transposable elements (MITEs) and is represented by multiple members. ${ }^{15}$ Corresponding to their origin from MITEs, miRNA-548 genes are primate specific with paralogs in the human genome. There are more than 3,500 putative hsamir-548 target genes and they have important roles in multiple biological processes. Analysis of their expression profiles and functional affinities also suggests cancer-related regulatory roles for hsamir-548. ${ }^{15}$ With more members in the gene family have been identified, it is quite necessary to further study this gene family's evolutionary and functional relationship based on their potential biological roles in complex regulatory network in ALL by systematic analysis.

The limitation of our study includes the small number of patient population and therefore, significant expression profiles of miRNAs were detected only in ALL patients.

In summary, our results indicate that miR-24-3p and $\mathrm{miR}-548 \mathrm{c}-3 \mathrm{p}$ can be used as potential noninvasive biomarkers for detecting ALL at the time of diagnosis and relapse.

\section{Acknowledgements:}

This work which is the part of "Establishment of Molecular Substructure Laboratory for Early Diagnosis of Cancer (TR62-09-03)" project was supported by Grants from Cukurova Development Agency (ÇKA), Mersin, Turkey.

\section{REFERENCES}

1. Stewart BW, Wild CP. World Cancer Report 2014. 3rd edition. Lyon, International Agency for Research on Cancer, World Health Organization, 2014: 482-495.

2. Ambros $V$. The evolution of our thinking about microRNAs. Nat Med 14: 1036-1040, 2008.

3. Ambros $V$. The functions of animal microRNAs. Nature 431: 350-355, 2004.

4. O'Connell RM, Baltimore D. MicroRNAs and hematopoietic cell development. Curr Top Dev Biol 99: 145-174, 2012. 
International Journal of Hematology and Oncology

5. Lawrie $\mathrm{CH}$. MicroRNAs and haematology: small molecules, big function. Br J Haematol 137: 503-512, 2007.

6. Calin GA, Dumitru CD, Shimizu M, et al. Frequent deletions and down-regulation of micro- RNA genes miR15 and miR16 at $13 q 14$ in chronic lymphocytic leukemia. Proc Natl Acad Sci USA 99: 15524-15529, 2002.

7. Esquela-Kerscher A, Slack FJ. Oncomirs - microRNAs with a role in cancer. Nat Rev Cancer 6: 259-269, 2006.

8. Lujambio A, Calin GA, Villanueva A, et al. A microRNA DNA methylation signature for human cancer metastasis. Proc Natl Acad Sci USA 105: 13556-13561, 2008.

9. Calin GA, Croce CM. MicroRNA signatures in human cancers. Nat Rev Cancer 6: 857-866, 2006.

10. Gounaris-Shannon S, Chevassut T. The role of miRNA in haematological malignancy. Bone Marrow Res 2013: 1-12, 2013.

11. Lawrie $\mathrm{CH}$. MicroRNAs in hematological malignancies. Blood Reviews 27: 143-154, 2013.

12. Mitchell PS, Parkin RK, Kroh EM, et al. Circulating miRNAs as stable blood-based markers for cancer detection. Proc Natl Acad Sci USA 105: 10513-10518, 2008.

13. Mi S, Lu J, Sun M, et al. MicroRNA expression signatures accurately discriminate acute lymphoblastic leukemia from acute myeloid leukemia. Natl Acad Sci USA 104: 1997119976, 2007.

14. Nguyen T, Rich A, Dahl A. MiR-24 promotes the survival of hematopoietic cells. PLOS ONE 8: 1-8, 2013.

15. Piriyapongsa J, Jordan IK. A Family of Human MicroRNA Genes from Miniature Inverted-Repeat Transposable Elements. PLoS ONE 2: 1-11, 2007.

\section{Correspondence}

Dr. Anıl TOMBAK

Mersin Üniversitesi Tıp Fakültesi

Hematoloji Anabilim Dalı

Ciftlik Kampüsü, Yenişehir

MERSIN / TURKEY

Tel: (+90-532) 3460767

Fax: (+90-324) 2410092

e-mail: aniltombak@mersin.edu.tr 